\title{
A táplálkozással kapcsolatos attitúdök, magatartás és információkeresés vizsgálata és összefüggése szociodemográfiai és pszichológiai változókkal serdülők körében
}

\author{
Szabó Katalin ${ }^{1}$. Pikó Bettina dr. ${ }^{2}$ \\ Szegedi Tudományegyetem, 'Bölcsészettudományi Kar, Neveléstudományi Doktori Iskola, \\ ${ }^{2}$ Általános Orvostudományi Kar, Magatartástudományi Intézet, Szeged
}

\begin{abstract}
Bevezetés: Egészségi állapotunk megőrzésében kulcsfontosságú a táplálkozás. Ezért a megfelelő étkezési szokások kialakítása igen fontos a serdülőkorban. Az étkezési magatartást olyan személyiségjegyek is befolyásolják, mint például az énhatékonyság, az optimizmus/pesszimizmus és az önkontroll.

Célkitüzés: Célunk a serdülők étkezéssel kapcsolatos attitüdjeinek, magatartásának és az őket befolyásoló információforrásoknak a feltérképezése, valamint ezek szociodemográfiai és pszichológiai változókkal való kapcsolatának vizsgálata volt.

Módszer: A résztvevők középiskolások voltak $(\mathrm{n}=277 ; 54 \%$ fiú; átlagéletkor: 16 év; szórás = 1,25). Önkitöltős kérdőívünk szociodemográfiai, étkezési magatartásra, attitűdökre és információkra vonatkozó kérdéseket, valamint három pszichológiai skálát tartalmazott.

Eredmények: Faktoranalízissel kialakítottuk az étkezési magatartás (egészségtudatos, nem egészségtudatos, nyersételalapú), az attitűdök (elutasító, ambivalens, elfogadó) és az információszerzés (laikus, szakértő, internet) főbb faktorait. A korrelációelemzések szerint bár a serdülők meglehetősen egészségtudatosak a táplálkozási magatartás és attitüdök terén, megjelenik az elutasítás és az ambivalencia is. Az énhatékonyság, az önkontroll és az optimizmus nemcsak az egészségtudatos magatartás és az elfogadó attitüd kialakulásában, hanem a nem egészségtudatos magatartás és attitűd elutasításában is szerepet játszott. Az egészségtudatos táplálkozási magatartás összefügg a jobb anyagi helyzettel, a szülők magasabb iskolai végzettségével, de kevésbé a nemmel. Az információválasztást részben szociodemográfiai változók is befolyásolják: a szakértői forrásokat elsősorban a lányok, a gimnazisták és a jó tanulók választják.

Következtetések: Adataink felhívják a figyelmet, hogy a serdülők táplálkozási szokásainak megismerése rendkívül fontos nemcsak a magatartás, hanem az attitűd és az információ szintjén is. Ez az életszakasz a gyermekkori táplálkozási szocializáció szempontjából nagyon lényeges, hiszen egyre inkább autonómmá válnak a fiatalok döntései ezen a téren is.
\end{abstract}

Orv Hetil. 2018; 159(51): 2183-2192.

Kulcsszavak: serdülők, táplálkozás, pszichológiai tényezők, szociodemográfiai jellemzők

\section{Study of eating attitudes, behaviour and information-seeking in relation to sociodemographic and psychological factors among adolescents}

Introduction: Nutrition is one of the key factors in health maintainance. So developing appropriate eating habits is very important in adolescence. Dietary behaviour may be influenced by certain aspects of personality, e.g., self-efficacy, optimism/pessimism and self-control.

Aim: We explored adolescents' eating behaviour, attitudes, and information seeking, and their relationship with psychological and sociodemographic factors. 
Method: Participants were high school students ( $\mathrm{n}=277 ; 54 \%$ boys; mean age: 16 years; $\mathrm{SD}=1.25)$. Our self-administered questionnaire contained items on sociodemographics, eating behaviour and attitudes, and information-seeking as well as three psychological scales.

Results: We explored the main factors of behaviour (health-conscious, nonconscious, raw-based), attitudes (rejecting, ambivalent and accepting), and information-seeking (lay, professional, Internet) using factor analysis. Correlation analyses revealed adolescents' nutrition-related behaviour and attitudes were rather health-conscious, but rejecting and ambivalence in their behaviour and attitudes appeared as well. Self-efficacy, self-control and optimism played a role not only in developing health-conscious behaviour and accepting attitude but also in avoiding the nonconscious behaviour and rejecting attitude. Health-conscious behaviour was associated with higher socioeconomic status and parents' schooling but less with gender. Information-seeking was partly influenced by certain sociodemographics: professional resources were preferred by girls, students from grammar schools, and those with better school achievement.

Conclusions: Our data draw attention to the extraordinary importance of mapping adolescent dietary habits; not only their behaviours but also attitudes and information-seeking. This life period is significant in terms of childhood nutrional socialization since youth's decisions become more and more autonomous in this field as well.

Keywords: adolescents, nutrition, psychological factors, sociodemographics

Szabó K, Pikó B. [Study of eating attitudes, behaviour and information-seeking in relation to sociodemographic and psychological factors among adolescents]. Orv Hetil. 2018; 159(51): 2183-2192.

(Beérkezett: 2018. május 19.; elfogadva: 2018. június 8.)

Az egészségi állapotunkat befolyásoló tényezők közül a legnagyobb hatása az életmódunknak van [1]. A táplálkozással összefüggő megbetegedések Európa-szerte kiemelt népegészségügyi problémát jelentenek [2]. Egy 2014-es felmérés szerint hazánk felnőtt lakosságának csaknem a kétharmada túlsúlyos vagy elhízott [3]. Az elhízás, a magas vérnyomás és az egyéb betegségek gyakran gyermek- és serdülőkorban kezdődnek [4]. A serdülókor az életmód és az étkezési magatartás szempontjából igen kritikus életszakasz [5, 6]. Ebben az életkorban a fiatalokra még hatással van a szülóii modell, viszont egyre jobban befolyásolják óket a kortársaik és a média $[7,8]$.

Az étkezési magatartást jellemző szempontok a menynyiség és a minőség, valamint az étkezés körülményeivel összefüggő környezeti hatások [9]. A magyar serdülók 29,4\%-a soha nem reggelizik rendesen tanítási napokon, és a fiatalok nagyobbik részére nem jellemző, hogy a szüleivel étkezzen. Az étrend összetétele szempontjából az egészséges étkezési magatartás (például zöldség- és gyümölcsfogyasztás) javuló tendenciát mutat, bár a nemzetközi átlagot így sem éri el [8]. A pozitív változások ellenére az egészségkockázatos étkezés (például édesség-, energiaital-, gyorsételfogyasztás) még mindig jelentős arányban jelenik meg a fiataloknál Európa-szerte [10], így hazánkban is $[5,11]$.

Egy attitűdvizsgálatban a serdülók az egészséges étkezést a zöldség-, gyümölcs- és salátafogyasztással azonosították, illetve kevésbé vonzó és szinte kivitelezhetetlen magatartásként jellemezték. Az ellenvetésekhez tartozott az étel íze és kinézete, a kisebb mértékú jóllakottság érzése, valamint az, hogy fogyasztásuk több időt és eröfeszítést igényel [12]. Egy másik vizsgálatban a serdülók attitúdjeit társaik ételpreferencáival kapcsolatban elemezték: az egészséges ételek (például gyümölcsök, zöld- ségek) fogyasztását alulbecsülték, míg a kevésbé egészséges ételek (például édességek, cukros üdítők) fogyasztását túlbecsülték a valódi adatokhoz képest [13].

Nem mellékes az az információforrás sem, amelyból a serdülő́k az étkezési szokásokról vagy az ételek egészséges és egészségkockázatos voltáról tájékozódnak. Ezért érdemes azt is vizsgálni, hogy milyen forrásból szereznek információt az étkezésről. A médiát, a televíziós reklámokat és a hírességeket gyakran megemlítik a fiatalok mint információforrást [12]. Egy hazai vizsgálat szerint a serdülő́k hiteles információforrásként az orvosokat jelölték meg, őket követték a szüloók, az internet és a tanárok [14]. Korábban az internet helyett inkább az újságokat és a televíziót említették [5]. Az egészségmúveltség fontos eleme a táplálkozásról szóló információk kezelése. A hiteles információ megtalálásának esélye akkor nagyobb, ha a fiatal az iskolában jár egészségügyi kurzusra, tanácsot kap egy családtagjától, ha kellőképpen fel van készülve arra, hogy egy online információt több forrásból is ellenőrizni tudjon, és megfelelő énhatékonysággal rendelkezik [15]. Úgy tünik tehát, a személyiségbeli tényezőknek, pszichológiai jellemzóknek is fontos szerep jut az információ megszerzésében, az attitúdök kialakításában és a magatartási döntésekben.

Az énhatékonyság hiánya következetesen előre jelezte a zsír- és cukorfogyasztást [16]. Emellett általánosságban szignifikánsan elősegítette mind a fiúk, mind pedig a lányok egészséges étkezési magatartását [17], különösen a zöldség- és gyümölcsfogyasztást [18]. Az optimizmus/pesszimizmus is szerepet játszik az egészséges táplálkozás fenntartásában: az egészségesebb ételeket fogyasztók inkább optimisták voltak [19]. Továbbá az optimistább nók alacsonyabb testtömeg (BMI)-indexszel rendelkeztek [20]. Serdülő́korban azonban az opti- 
mizmus irreális is lehet, ami az egészségtelen étkezéshez kapcsolódó kockázatok alulbecsléséhez vezethet [21]. $\mathrm{Az}$ önkontrollal rendelkező fiatalok kevesebb egészségtelen nassolnivalót fogyasztanak, különösen a fiatalabb serdülők [22]. Ezzel ellentétes eredmények szerint az önkontroll étkezést és testsúlyt szabályozó hatása viszonylag alacsony [23].
Jelen kutatásunk fókuszába a serdülők táplálkozással kapcsolatos három fö elemét helyeztük: a magatartást, az attitűdöt és az információt. Célkitűzésünk volt megvizsgálni, hogy egyes szociodemográfiai tényezők és a fent említett pszichológiai faktorok milyen kapcsolatban állnak az étkezési magatartással, attitűddel és a táplálkozásról szóló információforrásokkal.

1. táblázat |A pszichológiai változók leíró statisztikái a szociodemográfiai változók tükrében

\begin{tabular}{|c|c|c|c|c|c|c|c|c|}
\hline \multirow[t]{3}{*}{ Változók } & \multicolumn{2}{|c|}{ Énhatékonyság } & \multicolumn{2}{|c|}{ Pesszimizmus } & \multicolumn{2}{|c|}{ Optimizmus } & \multicolumn{2}{|c|}{ Önkontroll } \\
\hline & M & $\mathrm{t}(\mathrm{df})$ & M & $\mathrm{t}(\mathrm{df})$ & M & $\mathrm{t}(\mathrm{df})$ & M & $\mathrm{t}(\mathrm{df})$ \\
\hline & $S D$ & $p$ & $S D$ & $p$ & $S D$ & $p$ & $S D$ & $p$ \\
\hline \multicolumn{9}{|l|}{$\mathrm{Nem}$} \\
\hline \multirow[t]{2}{*}{ Fiú } & 29,4 & \multirow{4}{*}{$\begin{array}{c}0,17(250) \\
0,86\end{array}$} & 6,1 & \multirow{4}{*}{$\begin{array}{c}0,96(262) \\
0,34\end{array}$} & 7,5 & & 19,7 & \multirow{4}{*}{$\begin{array}{c}-1,60(255) \\
0,11\end{array}$} \\
\hline & 5,3 & & 2,7 & & 4,5 & $0,23(259)$ & 6,6 & \\
\hline \multirow{2}{*}{ Lány } & 29,3 & & 5,7 & & 7,3 & 0,82 & 21,1 & \\
\hline & 7,9 & & 3,1 & & 3,2 & & 7,0 & \\
\hline \multicolumn{9}{|l|}{ Lakóbely } \\
\hline \multirow[t]{2}{*}{ Város } & 30,1 & \multirow{4}{*}{$\begin{array}{c}2,58(245) \\
0,01\end{array}$} & 6,0 & \multirow{4}{*}{$\begin{array}{c}0,07(256) \\
0,95\end{array}$} & 7,7 & & 20,8 & \multirow{4}{*}{$\begin{array}{c}1,54(250) \\
0,13\end{array}$} \\
\hline & 7,2 & & 4,2 & & 4,5 & $1,55(254)$ & 6,6 & \\
\hline \multirow{2}{*}{ Község, falu } & 28,1 & & 5,9 & & 6,9 & 0,12 & 19,5 & \\
\hline & 5,3 & & 2,5 & & 2,7 & & 6,9 & \\
\hline \multicolumn{9}{|l|}{ Anyagi belyzet } \\
\hline \multirow{2}{*}{ Alsó- és középosztály } & 28,9 & \multirow{4}{*}{$\begin{array}{c}-2,64(245) \\
0,01\end{array}$} & 6,0 & \multirow{4}{*}{$\begin{array}{c}-0,37(256) \\
0,71\end{array}$} & 7,1 & & 20,4 & \multirow{4}{*}{$\begin{array}{c}0,86(250) \\
0,78\end{array}$} \\
\hline & 5,2 & & 2,5 & & 4,1 & $-1,32(255)$ & 6,8 & \\
\hline Felsőközép- és felső & 30,1 & & 6,1 & & 7,8 & 0,18 & 20,2 & \\
\hline osztály & 8,6 & & 3,5 & & 3,5 & & 7,0 & \\
\hline \multicolumn{9}{|l|}{ Szülók családi állapota } \\
\hline Teljes család & 28,4 & & 5,6 & & 7,1 & & 20,7 & \\
\hline & 5,2 & $-3,14(249)$ & 2,5 & $-2,59(259)$ & 2,5 & $-1,16(257)$ & 6,7 & $1,15(254)$ \\
\hline Egyszülős család & 31,2 & 0,00 & 6,5 & 0,01 & 7,9 & 0,25 & 19,7 & 0,25 \\
\hline (elvált, özvegy) & 8,7 & & 3,4 & & 5,7 & & 6,9 & \\
\hline Iskola tipusa & & & & & & & & \\
\hline Szakközép, szakiskola & 28,2 & & 6,5 & & 6,5 & & 19,1 & \\
\hline & 5,5 & $-1,86(250)$ & 2,6 & $2,18(262)$ & 2,9 & $-2,38(259)$ & 7,3 & $-2,04(255)$ \\
\hline Szakgimnázium, & 29,9 & 0,06 & 5,6 & 0,03 & 7,8 & 0,02 & 20,9 & 0,04 \\
\hline gimnázium & 7,1 & & 3,0 & & 4,3 & & 6,5 & \\
\hline Apa iskolai végzettsége & & & & & & & & \\
\hline Alap- és középfokú & 29,0 & & 6,0 & & 7,2 & & 20,4 & \\
\hline & 5,2 & $-1,59(204)$ & 2,7 & $0,55(251)$ & 4,1 & $-1,24(248)$ & 6,6 & $-0,19(245)$ \\
\hline Felsőfokú & 31,0 & 0,12 & 5,8 & 0,58 & 7,9 & 0,22 & 20,6 & 0,85 \\
\hline & 9,6 & & 3,5 & & 3,6 & & 7,5 & \\
\hline Anya iskolai végzettsége & & & & & & & & \\
\hline Alap- és középfokú & 28,9 & & 6,0 & & 7,2 & & 20,6 & \\
\hline & 5,4 & $-1,91(244)$ & 2,6 & $0,40(256)$ & 4,2 & $-1,02(253)$ & 6,5 & $0,73(250)$ \\
\hline Felsőfokú & 30,6 & 0,06 & 5,8 & 0,69 & 7,7 & 0,31 & 19,9 & 0,47 \\
\hline & 8,5 & & 3,5 & & 3,5 & & 7,4 & \\
\hline Gyakori osztályzatok & & & & & & & & \\
\hline 4-5-ös & 30,2 & & 5,7 & & 7,9 & & 21,5 & \\
\hline & 7,5 & $2,21(242)$ & 3,1 & $-0,40(252)$ & 4,9 & $1,91(249)$ & 6,6 & $2,90(246)$ \\
\hline $1-3$-as & 28,3 & 0,03 & 5,9 & 0,69 & 6,9 & 0,06 & 19,0 & 0,00 \\
\hline & 5,4 & & 2,7 & & 2,6 & & 6,9 & \\
\hline
\end{tabular}

Kétmintás t-próbák. 


\section{Módszer}

Az adatgyújtésre 2017-ben a Neveléstudományi Doktori Iskola etikai engedélyének megszerzése után került sor. Vizsgálatunkban 277 középiskolás vett részt (54\% fiú; 14-21 évesek, átlag = 16 év; szórás $=1,25)$. A megkérdezettek 31\%-a szakiskolába, 27\%-a szakgimnáziumba és 42\%-a gimnáziumba járt Szegeden. Az adatgyújtéshez papíralapú, önkitöltős kérdőívet használtunk, amely kiterjedt a szociodemográfiai jellemzőkre (kor, nem, családi struktúra, társadalmi helyzet önbesorolása, lakóhely, szülők iskolai végzettsége, tanulmányi eredmény), az étkezési magatartásra és attitúdökre, illetve a táplálkozással kapcsolatban használt hírforrásokra, valamint pszichológiai skálákra (optimizmus/pesszimizmus, önkontroll, énhatékonyság).

Az étkezési magatartás, az attitúdök, valamint a táplálkozással kapcsolatos információszerzés forrásainak feltérképezését a Szúcs, Szabó és Bánáti tanulmányában (2015) szereplő módszertan kérdéseivel végeztük [24]. Az étkezési magatartás és attitûdök meghatározásához a megkérdezetteknek 10-10 állításra kellett válaszolniuk 1-tôl 5 -ig terjedő skálán $(1=$ egyáltalán nem jellemző rám/egyáltalán nem értek egyet, $5=$ teljesen jellemző rám/teljesen egyetértek). Végül a 14 hírforrásból (például tévéreklámok, internet) kellett megjelölniük ötfokú Likert-skálán, hogy számukra mennyire fontosak $(1=$ kevésbé fontos, $5=$ meghatározó). A magatartás, az attitûdök és a hírforrások itemeit faktoranalízisnek vetettük alá, melyben az l-nél nagyobb faktorsúlyú változókat vontuk be a végső faktorstruktúrába.

Az énhatékonyság mérésére az Énhatékonyság Skála validált magyar verzióját alkalmaztuk [25]. A skála 10 itemből áll, amelyre négypontos skálán kell válaszolni ( 1 = egyáltalán nem jellemző, $4=$ teljesen jellemző). Saját mintánkon a megbízhatósági mutató (Cronbach-alfa) 0,90 lett. A Life Orientation Test [26] magyar verzióját alkalmaztuk [27] az optimizmus és a pesszimizmus feltárására. A skála 10 állításával kapcsolatos egyetértést ötfokú Likert-skálán kellett bejelölni. A méróeszköz megbízhatósága (Cronbach-alfa): 0,65 lett. Az önkontrollt Tangney, Baumeister és Boone (2004) úgynevezett Énkontroll Skálájával mértük [28], amely szintén 10 itemből áll. A válaszadáshoz ötfokú Likert-skálán kellett megjelölni, hogy az állítás mennyire jellemző a kitöltőre ( 1 = egyáltalán nem jellemző rám, $5=$ teljesen jellemző rám). A skála megbízhatósági mutatója a saját mintán: 0,73 .

\section{Eredmények}

Az 1. táblázatban a pszichológiai skálák leíró statisztikái láthatók. Megállapítható, hogy szignifikánsan magasabb azok énhatékonysága, akik városban laknak ( $\mathrm{t}(245)=$ $2,58, \mathrm{p}<0,01)$, akik jobb anyagi körülmények között élnek $(t(245)=-2,64, p<1,01)$, akiknek a szülei elváltak vagy özvegyek $(\mathrm{t}(249)=-3,14, \mathrm{p}<0,01)$, akik (szak) gimnáziumban tanulnak $(\mathrm{t}(250)=-1,86, \mathrm{p}=0,06)$,

2. táblázat |Az étkezési magatartás faktorstruktúrája

\begin{tabular}{|c|c|c|c|}
\hline & \multicolumn{3}{|c|}{ Faktorok a sajátértékekkel $(n=277)$} \\
\hline & $\begin{array}{l}\text { 1. faktor } \\
(2,68)\end{array}$ & $\begin{array}{l}\text { 2. faktor } \\
(1,50)\end{array}$ & $\begin{array}{l}\text { 3. faktor } \\
(1,30)\end{array}$ \\
\hline Főként nyersen fogyasztom el a gyümölcsöket. & - & - & 0,863 \\
\hline $\begin{array}{l}\text { Tudom, hogy a zöldségekben/gyümölcsökben milyen egészséges } \\
\text { összetevők vannak. }\end{array}$ & 0,348 & - & - \\
\hline $\begin{array}{l}\text { Érdekelnek az egészséges táplálkozással kapcsolatos újságcikkek, } \\
\text { tévéműsorok. }\end{array}$ & 0,702 & - & - \\
\hline Egészségesen táplálkozom. & 0,747 & - & - \\
\hline $\begin{array}{l}\text { Hajlandó vagyok többet fizetni azért, hogy étrendem egészséges } \\
\text { legyen. }\end{array}$ & 0,794 & - & - \\
\hline Fóként nyersen fogyasztom el a zöldségeket. & - & - & 0,579 \\
\hline Rendszeresen mozgok az egészségem megőrzése érdekében. & 0,530 & - & - \\
\hline Köretként inkább zöldséget fogyasztok, mint burgonyát vagy rizst. & 0,645 & - & - \\
\hline $\begin{array}{l}\text { Nem engedhetem meg magamnak az egészséges táplálkozást, } \\
\text { az túlságosan drága lenne. }\end{array}$ & - & 0,760 & - \\
\hline $\begin{array}{l}\text { Nem tudom pontosan, hogyan kellene egészségesen táplálkoznom, } \\
\text { mit kellene rendszeresen ennem, illetve, hogy mit nem szabadna } \\
\text { fogyasztanom. }\end{array}$ & - & 0,647 & - \\
\hline$\%$-os variancia & 26,776 & 15,038 & 12,958 \\
\hline Faktorok elnevezése & $\begin{array}{l}\text { Egészségtudatos } \\
\text { magatartás }\end{array}$ & $\begin{array}{l}\text { Nem egészségtudatos } \\
\text { magatartás }\end{array}$ & $\begin{array}{l}\text { Tudatos nyersétel- } \\
\text { alapú táplálkozás }\end{array}$ \\
\hline
\end{tabular}


3. táblázat |Az egészséges táplálkozáshoz kapcsolódó attitúdök faktorstruktúrája

\begin{tabular}{|c|c|c|c|}
\hline & \multicolumn{3}{|c|}{ Faktorok a sajátértékekkel $(n=277)$} \\
\hline & $\begin{array}{l}\text { 1. faktor } \\
(1,83)\end{array}$ & $\begin{array}{l}\text { 2. faktor } \\
(1,79)\end{array}$ & $\begin{array}{l}\text { 3. faktor } \\
(1,27)\end{array}$ \\
\hline $\begin{array}{l}\text { Nem lehet egységes receptet adni az egészséges táplálkozásra, } \\
\text { mindenkinek másra kell vigyáznia. }\end{array}$ & - & 0,509 & - \\
\hline $\begin{array}{l}\text { Sokkal többet tudunk arról, hogy mit kellene megváltoztatnunk } \\
\text { ahhoz, hogy egészségesen táplálkozzunk, de sajnos keveset } \\
\text { teszünk érte. }\end{array}$ & - & 0,716 & - \\
\hline $\begin{array}{l}\text { Egészséges embernél elég arra figyelni, hogy változatos, } \\
\text { kiegyensúlyozott és mértékletes legyen a táplálkozás. }\end{array}$ & - & - & 0,700 \\
\hline $\begin{array}{l}\text { Hiába mondják, hogy egészséges valami, ha nem ízlik, nem } \\
\text { eróltetem. }\end{array}$ & 0,392 & - & - \\
\hline $\begin{array}{l}\text { Az egészséges táplálkozás nem önmagunk sanyargatása, hanem } \\
\text { ellenkezőleg: örömforrás. }\end{array}$ & - & - & 0,704 \\
\hline $\begin{array}{l}\text { Fitoszterinek, flavonoidok, gyökfogók, probiotikumok - az } \\
\text { ember csak kapkodja a fejét a számára ismeretlen fogalmak } \\
\text { hallatán és egyre tanácstalanabb, hogy mit is kell tennie, ha } \\
\text { egészségesen akar táplálkozni. }\end{array}$ & - & 0,645 & - \\
\hline Az egészséges táplálkozás nagyon költséges. & - & 0,397 & - \\
\hline $\begin{array}{l}\text { Az egészséges táplálkozásra vonatkozó ismeretek folyamatosan } \\
\text { változnak, bővülnek, ezért nehéz követni azokat. }\end{array}$ & - & 0,472 & - \\
\hline Az válik igazán egészségünkre, ami ízlik is. & 0,556 & - & - \\
\hline $\begin{array}{l}\text { Már többször megpróbáltam egészségesen táplálkozni, de } \\
\text { átmeneti önsanyargatás után visszatértem a megszokott } \\
\text { gyakorlathoz. }\end{array}$ & 0,663 & - & - \\
\hline $\begin{array}{l}\text { Az egészséges táplálkozásról nekem mindig a fogyókúra jut } \\
\text { eszembe. }\end{array}$ & 0,749 & - & - \\
\hline$\%$-os variancia & 16,667 & 16,268 & 11,559 \\
\hline Faktorok elnevezése & $\begin{array}{l}\text { Egészséges táplálkozást } \\
\text { elutasító attitűd }\end{array}$ & $\begin{array}{l}\text { Egészséges táplálkozással } \\
\text { ambivalens attitűd }\end{array}$ & $\begin{array}{l}\text { Egészséges táplálkozást } \\
\text { elfogadó attitûd }\end{array}$ \\
\hline
\end{tabular}

akiknek az édesanyja magasabb iskolai végzettségü $(\mathrm{t}(244)=-1,91, \mathrm{p}=0,06)$, és akik jobb jegyeket kapnak (t $(242)=2,21, \mathrm{p}=0,03)$. Pesszimistábbak azok, akik egyszülős családban élnek ( $\mathrm{t}(259)=-2,59, \mathrm{p}<0,01)$, és akik szakközépiskolába járnak ( $\mathrm{t}(262)=2,18, \mathrm{p}=0,03$ ). Ezzel szemben optimistábbak és nagyobb önkontrollal rendelkeznek a (szak)gimnáziumok tanulói ( $\mathrm{t}$ (259) = $-2,38, \mathrm{p}=0,02 ; \mathrm{t}(255)=-2,04, \mathrm{p}=0,04)$, és akik jobban teljesítenek az iskolában $(\mathrm{t}(249)=1,91, \mathrm{p}=0,06$; $\mathrm{t}(246)=2,9, \mathrm{p}<0,01)$ (1. táblázat).

A 2-4. táblázatban az étkezési magatartással és attitúdökkel, valamint az információszerzési módokkal kapcsolatos állítások faktoranalízissel nyert rotált, végső faktorstruktúráit láthatjuk. $\mathrm{Az}$ étkezési magatartáshoz kapcsolódóan három faktorváltozót különítettünk el (2. táblázat): (1) az egészségtudatos magatartást, (2) a nem egészségtudatos magatartást és (3) a tudatos, nyersételalapú táplálkozást. Az első faktorba olyan változók tartoznak, mint például „Hajlandó vagyok többet fizetni azért, hogy étrendem egészséges legyen”. A harmadik faktor is egészségtudatos, de kifejezetten nyers ételeket preferáló állításokat jelöl („Főként nyersen fogyasztom el a zöldségeket”). A második faktor ezzel szemben olyan állítást tartalmaz, mint például „Nem tudom pontosan, hogyan kellene egészségesen táplálkoznom, mit kellene rendszeresen ennem, illetve, hogy mit nem szabadna fogyasztanom". A faktorok a variancia 54,7\%-át magyarázzák meg öszszességében (2. táblázat).

A táplálkozáshoz kapcsolódó attitűdök alapján szintén három faktorváltozót tudtunk létrehozni (3. táblázat): (1) az egészséges táplálkozást elutasító, (2) ambivalens és (3) elfogadó attitűdöt. Az elutasító attitűd kifejezetten negatívan áll hozzá az egészséges táplálkozáshoz (például „Hiába mondják, hogy egészséges valami, ha nem izlik, nem erôltetem”). A második faktor elismeri ugyan az egészséges táplálkozás fontosságát, de kételyeinek is hangot ad, például az egészséges ételek ára vagy az ismeretek folyamatos változása s így a magas bizonytalansági tényező miatt. A harmadik faktor viszont pozitív attitüdhöz kapcsolódik (például „Az egészséges táplálkozás nem önmagunk sanyargatása, hanem ellenkezőleg: örömforrás”). Ezek a faktorok összesen a variancia 44,5\%-át magyarázzák meg (3. táblázat).

Végül az információszerzés forrásaival kapcsolatos három faktor: (1) a laikus, (2) a szakértői forrásokra és (3) az internetre alapozott faktor (4. táblázat). A laikus for- 


\begin{tabular}{|c|c|c|c|}
\hline & Fakt & ok a sajátértékekkel ( $n$ & \\
\hline & $\begin{array}{l}\text { 1. faktor } \\
(3,64)\end{array}$ & $\begin{array}{l}\text { 2. faktor } \\
(2,40)\end{array}$ & $\begin{array}{l}\text { 3. faktor } \\
(1,31)\end{array}$ \\
\hline Internet & - & - & 0,845 \\
\hline Iskolában tanultak & - & 0,497 & - \\
\hline Élelmiszerek jelölése, címkeinformációk & - & 0,614 & - \\
\hline Egészségügyi kiadványok, kézikönyvek & - & 0,715 & - \\
\hline Termékismertetők, szórólapok & 0,634 & - & - \\
\hline Szomszéddal, ismerőssel, baráttal való tapasztalatcsere & 0,290 & - & - \\
\hline $\begin{array}{l}\text { Egészségügyi ellátás során kapott személyes tájékoztatás (orvos, dietetikus, } \\
\text { gyógyszerész stb.) }\end{array}$ & - & 0,682 & - \\
\hline Televíziómúsorok & 0,722 & - & - \\
\hline Szakboltokban (például biobolt, fitotéka) szakképzett eladó felvilágosítása & - & 0,727 & - \\
\hline Női magazinok életmóddal, egészséges táplálkozással kapcsolatos cikkei & 0,527 & - & - \\
\hline $\begin{array}{l}\text { Ingyenes kiadványok témába vágó írásai (például Patikatükör, ételt házhoz } \\
\text { szállító cégek kiadványai stb.) }\end{array}$ & 0,594 & - & - \\
\hline Rádiómüsorok & 0,718 & - & - \\
\hline Reklámok újságokban, plakátokon & 0,857 & - & - \\
\hline Tévéreklámok & 0,812 & - & - \\
\hline$\%$-os variancia & 25,983 & 17,147 & 9,384 \\
\hline Faktorok elnevezése & Laikus hírforrás & Szakértői hírforrás & Internet \\
\hline
\end{tabular}

rások elsősorban a barátok, ismerősök beszámolóit, szórólapokat, valamint a média különböző eszközeit jelentik (például női magazinok, tévéreklámok). A szakértői források az egészségügyi kiadványok mellett az egészségügyi ellátás során kapott személyes tájékoztatást is figyelembe vesznek. Az internet külön faktort képez, amelyet nem tudtunk a hitelesség szempontjából differenciálni. Ezek a faktorok a variancia $52 \%$-át határozzák meg összesen (4. táblázat).

A faktorok közötti szignifikáns összefüggések közül meg kell említeni, hogy míg az egészségtudatos magatartás elfogadó attitû́ddel korrelál $(\mathrm{r}=0,30, \mathrm{p}<0,001)$, addig a nem egészségtudatos táplálkozás az elutasító attitúddel $(\mathrm{r}=0,32, \mathrm{p}<0,001)$. Továbbá míg az egészségtudatos magatartás és elfogadó attitüd mellett az ambivalens, szkeptikus attitûd is a szakértői, az elutasító attitűd a laikus hírforrással mutatott pozitív kapcsolatot. $\mathrm{Az}$ internet mint forrás egyedül a tudatos nyersétel-alapú táplálkozással jelzett kapcsolatot $(\mathrm{r}=0,19, \mathrm{p}<0,01)$.

Az 5. táblázat az étkezéssel kapcsolatos faktorok (magatartás, attitűd és információ), valamint a pszichológiai változók közötti kétoldalú kapcsolatokat jellemző korrelációs együtthatókat tartalmazza. Az énhatékonyság és az önkontroll pozitív korrelációt mutat az egészségtudatos magatartással $(\mathrm{r}=0,28, \mathrm{p}<0,001 ; \mathrm{r}=0,3 \mathrm{l}, \mathrm{p}<0,001)$ és attitűddel $(\mathrm{r}=0,24, \mathrm{p}<0,001, \mathrm{r}=0,19, \mathrm{p}<0,001)$, míg negatív korrelációt a nem egészségtudatos magatartással $(\mathrm{r}=-0,14, \mathrm{p}<0,05 ; \mathrm{r}=-0,31, \mathrm{p}<0,001)$ és attitúddel $(\mathrm{r}=$ $-0,19, \mathrm{p}<0,001 ; \mathrm{r}=-0,19, \mathrm{p}<0,001)$. Az optimizmus pozitív kapcsolatban áll az egészségtudatos magatartással $(\mathrm{r}=0,18, \mathrm{p}<0,001)$ és attitűddel $(\mathrm{r}=0,19, \mathrm{p}<0,001)$. Továbbá az optimistábbak inkább a szakértői hírforrásokra $(\mathrm{r}=0,15, \mathrm{p}<0,05)$, a magasabb énhatékonysággal rendelkezők pedig leginkább az internetre $(r=0,16$, $\mathrm{p}<0,05)$ támaszkodtak információszerzés céljából (5. táblázat).

A 6. táblázat az étkezéssel kapcsolatos magatartási, attitűdbeli és információs faktorok, valamint a szociodemográfiai változók közötti összefüggéseket mutatja be. Az egészségtudatos magatartás pozitív kapcsolatban áll a jobb anyagi helyzettel $(\mathrm{r}=0,23, \mathrm{p}<0,001)$, a (szak)gimnáziumban tanulással $(\mathrm{r}=0,18, \mathrm{p}<0,001)$ és a szülők magasabb iskolai végzettségével (apa: $\mathrm{r}=0,18, \mathrm{p}<0,001$, anya: $\mathrm{r}=0,14, \mathrm{p}<0,05)$. A nem egészségtudatos magatartás viszont a falubeli lakóhellyel $(\mathrm{r}=0,17, \mathrm{p}<0,001)$, a rosszabb anyagi helyzettel $(\mathrm{r}=-0,23, \mathrm{p}<0,001)$, a szakiskolában tanulással $(\mathrm{r}=-0,17, \mathrm{p}<0,001)$ hozható kapcsolatba.

Az étkezési magatartáshoz kapcsolódó attitűdök tekintetében az elfogadás együtt járt az alacsonyabb korral $(\mathrm{r}=-0,15, \mathrm{p}<0,05)$, a jobb anyagi helyzettel $(\mathrm{r}=0,20$, $\mathrm{p}<0,001)$ és a (szak)gimnáziumba járással $(\mathrm{r}=0,18$, $\mathrm{p}<0,001)$. Az elutasítás kapcsolatot mutatott a női nemmel $(\mathrm{r}=0,13, \mathrm{p}<0,001)$ és az alacsonyabb anyagi helyzettel $(r=-0,13, p<0,05)$. Az ambivalencia pedig szignifikánsan összefüggött a nói nemmel $(r=0,15, p<0,05)$ és az iskola típusával, méghozzá nagyobb gyakorisággal a (szak)gimnáziummal $(\mathrm{r}=0,16, \mathrm{p}<0,05)$. 
Az egészséges táplálkozással összefüggő magatartások és attitűdök, valamint információszerzési módok korrelációs kapcsolatai a pszichológiai változókkal

\begin{tabular}{lcccc}
\hline & Énhatékonyság & Pesszimizmus & Optimizmus & Önkontroll \\
\hline Egészségtudatos magatartás & $0,28^{* *}$ & $-0,11$ & $0,18^{* *}$ & $0,31^{* *}$ \\
\hline Nem egészségtudatos magatartás & $-0,14^{*}$ & 0,07 & $-0,12$ & $-0,31^{* *}$ \\
\hline Tudatos nyersétel-alapú táplálkozás & 0,03 & 0,05 & 0,01 & $-0,01$ \\
\hline Egészséges táplálkozást elutasító attitúd & $-0,19^{* *}$ & 0,08 & $-0,08$ & $-0,19^{* *}$ \\
\hline Egészséges táplálkozással ambivalens attitúd & 0,02 & 0,07 & 0,02 & $-0,02$ \\
\hline Egészséges táplálkozást elfogadó attitűd & $0,24^{* *}$ & $-0,02$ & $0,19^{* *}$ & $0,19^{* *}$ \\
\hline Laikus hírforrás & $-0,03$ & $-0,04$ & $-0,03$ & $-0,13$ \\
\hline Szakértő́i hírforrás & 0,11 & $-0,04$ & $0,15^{*}$ & 0,03 \\
\hline Internet & $0,16^{*}$ & 0,05 & $-0,05$ & 0,01 \\
\hline
\end{tabular}

Korrelációs együtthatók $(\mathrm{r})$ értékei. Szignifikancia: ${ }^{*} \mathrm{p}<0,05 ;{ }^{*} \mathrm{p}<0,001$

6. táblázat $\mid$ Az egészséges táplálkozással összefüggő magatartások és attitűdök, valamint információszerzési módok korrelációs kapcsolatai a szociodemográfiai változókkal

\begin{tabular}{|c|c|c|c|c|c|c|c|c|c|}
\hline & $\begin{array}{l}\text { Nem } \\
1=\text { fiú } \\
2=\text { lány }\end{array}$ & Kor & $\begin{array}{l}\text { Lakóhely } \\
\begin{array}{l}1 \text { = város } \\
2=\text { falu, } \\
\text { község }\end{array}\end{array}$ & $\begin{array}{c}\text { Anyagi } \\
\text { helyzet } \\
1=a l s o ́, \\
\text { közép } \\
2= \\
\text { felsö-közép és } \\
\text { felsö }\end{array}$ & $\begin{array}{c}\text { Szülók } \\
\text { családi } \\
\text { állapota } \\
1 \text { = teljes } \\
\text { család } \\
2 \text { = egyszülös } \\
\text { család }\end{array}$ & $\begin{array}{c}\text { Iskola } \\
\text { típusa } \\
1= \\
\text { szakiskola } \\
2=(\text { szak }) \\
\text { gimnázium }\end{array}$ & $\begin{array}{l}\text { Apa iskolai } \\
\text { végzettsége } \\
1=\text { nem } \\
\text { felsöfokú } \\
2=\text { felsöfokú }\end{array}$ & $\begin{array}{c}\text { Anya iskolai } \\
\text { végzettsége } \\
1=n e m \\
\text { felsőfokú } \\
2=\text { felsófokú }\end{array}$ & $\begin{array}{c}\text { Jegyek } \\
\begin{array}{l}1=4-5-\ddot{o s} \\
2=1-3-a s\end{array}\end{array}$ \\
\hline $\begin{array}{l}\text { Egészségtudatos } \\
\text { magatartás }\end{array}$ & 0,10 & 0,01 & $-0,09$ & 0,23 ** & $-0,10$ & 0,18 ** & 0,18 ** & $0,14^{*}$ & $-0,04$ \\
\hline $\begin{array}{l}\text { Nem egészségtudatos } \\
\text { magatartás }\end{array}$ & $-0,10$ & 0,01 & 0,17 * * & $-0,23 * *$ & 0,06 & $-0,17^{* \text { * }}$ & $-0,02$ & $-0,04$ & 0,10 \\
\hline $\begin{array}{l}\text { Tudatos nyersétel-alapú } \\
\text { táplálkozás }\end{array}$ & 0,18 ** & $-0,06$ & $-0,02$ & 0,04 & $-0,01$ & $0,13^{*}$ & 0,08 & 0,11 & $-0,06$ \\
\hline $\begin{array}{l}\text { Egészséges táplálkozást } \\
\text { elutasító attitűd }\end{array}$ & $0,13^{*}$ & $-0,09$ & 0,10 & $-0,13^{*}$ & $-0,03$ & $-0,11$ & $-0,03$ & $-0,04$ & $-0,02$ \\
\hline $\begin{array}{l}\text { Egészséges táplálkozással } \\
\text { ambivalens attitűd }\end{array}$ & $0,15^{*}$ & 0,04 & $-0,11$ & $-0,04$ & $-0,04$ & $0,16^{*}$ & $-0,03$ & $-0,01$ & $-0,06$ \\
\hline $\begin{array}{l}\text { Egészséges táplálkozást } \\
\text { elfogadó attitűd }\end{array}$ & 0,03 & $-0,15$ * & $-0,08$ & $0,20^{* *}$ & 0,01 & $0,18 * *$ & 0,07 & 0,03 & $-0,07$ \\
\hline Laikus hírforrás & $-0,03$ & $-0,16^{*}$ & 0,18 * * & 0,01 & $-0,06$ & $-0,16^{*}$ & $-0,12$ & $-0,07$ & 0,13 * * \\
\hline Szakértői hírforrás & 0,21 ** & $-0,07$ & $-0,1$ & $-0,05$ & $-0,04$ & $0,25^{* *}$ & $-0,04$ & 0,04 & $-0,14^{* *}$ \\
\hline Internet & $-0,04$ & 0,10 & $-0,04$ & 0,07 & 0,08 & 0,11 & 0,08 & $0,13^{*}$ & 0,03 \\
\hline
\end{tabular}

Korrelációs együtthatók ( $\mathrm{r}$ ) értékei. Szignifikancia: ${ }^{*} \mathrm{p}<0,05 ;{ }^{*}{ }^{*} \mathrm{p}<0,001$

Végül a hírforrások tekintetében a laikus hírforrások használata kapcsolatban állt a korral $(\mathrm{r}=-0,16, \mathrm{p}<0,05)$ és a falubeli lakóhellyel $(r=0,18, p<0,001)$, ezzel szemben a szakértői hírforrások használata a nói nemmel $(\mathrm{r}=$ $0,21, p<0,001)$. A laikus hírforrások keresése a gimnáziumba járók körében csökken $(\mathrm{r}=-0,16, \mathrm{p}<0,05)$, és szignifikánsan nő a szakértői hírforrások gyakorisága $(\mathrm{r}=$ $0,25, \mathrm{p}<0,001)$ a szakiskolásokhoz képest. Az információszerzés korrelál a jegyekkel is: a jobb jegyekkel rendelkező fiatalok inkább támaszkodnak a szakértői forrásokra $(\mathrm{r}=-0,14, \mathrm{p}<0,01)$, míg a kevésbé jó tanulók a laikus hírforrásokra $(\mathrm{r}=0,13, \mathrm{p}<0,01)$. Az internethasználat csak az anya felsőfokú végzettségével állt kapcsolatban $(\mathrm{r}=0,13, \mathrm{p}<0,05)$ (6. táblázat).

\section{Megbeszélés}

Jelen kutatásunkban megvizsgáltuk, hogy a serdülők táplálkozással kapcsolatos magatartása, attitűdjei és az általuk használt információforrások milyen kategóriákba sorolhatók, illetve hogy ezek a faktorok milyen összefüg- 
géseket mutatnak egyes szociodemográfiai és személyiségbeli jellemzőkkel.

Mindhárom táplálkozást jellemző változócsoport (magatartás, attitűd, információ) esetében három faktort sikerült azonosítani. A magatartás szintjén elkülönült az egészségtudatos, a nem egészségtudatos magatartás, valamint egy kifejezetten a nyersétel-alapú étrendet preferáló táplálkozás, amely a legkisebb arányban volt jelen a mintában. Bár a legnagyobb arányban a fiatalok egészségtudatos magatartást követtek, jelen van az ellenkezője is, ami megfelel a szakirodalomban fellelhető adatoknak $[5,10,11]$. Ez azt a kettősséget jelzi, hogy a fiatalok - bár egyre egészségtudatosabbak a táplálkozás terén az egészségkockázatos ételekről sem mondanak le. Egy friss tanulmány, amely 11-18 évesek táplálkozási szokásairól számolt be, ezt úgy fogalmazta meg, hogy a fiatalok táplálkozására elsősorban a kiegyensúlyozatlan élelmiszer-fogyasztás jellemző [29].

Az egészségtudatos táplálkozási magatartás összefügg a jobb anyagi helyzettel, a szülők magasabb iskolai végzettségével, és a gimnazistákra is inkább jellemző, mint a szakiskolásokra. Az egyenlőtlenségek egészségi állapotra gyakorolt hatása régóta ismeretes, a táplálkozásban pedig részben az ismeretek, részben az anyagi lehetőségek is meghatározóak $[5,30]$. A nem egészségtudatos magatartás az anyagiak mellett a lakóhellyel is összefügg: a falun élő fiatalokra inkább jellemző, mint városban lakó társaikra. A nemmel kapcsolatban azt vártuk volna, hogy a lányok tudatosabban táplálkoznak [7], azonban egyedül a nyersétel-alapú étrend preferálása volt rájuk jellemzőbb.

Az attitüdök szintjén az egészséges étkezést elfogadó, illetve elutasító hozzáállás mellett ambivalens, szkeptikus viszonyulás is megmutatkozott, amely a lányokra és a gimnazistákra volt jellemzőbb. A magatartás és az attitűd között, bár szignifikáns, de nem túlzottan erôs kapcsolat igazolható, amely jelzi, hogy a megvalósításhoz a viszonyulás még nem elégséges. Sok egyéb, külső tényezôtől is függ, mint például az idő, az anyagiak vagy a ráfordított energia, és a megítélés sem egyértelmű [12, 13]. Személyiségbeli jellemzők szintén kapcsolatban állnak a táplálkozási magatartással és attitűdökkel: az énhatékonyság, az önkontroll és az optimizmus különösen fontos az egészségtudatos magatartás és az elfogadó attitüd kialakulásában, ami korábbi eredményeknek felel meg [17-19]. Az előbbi két skála a nem egészségtudatos magatartás és attitűd elutasításában is szerepet játszik, ami szintén más eredményekhez hasonló [16, 22]. Az önkontrollnak tehát van szerepe a táplálkozási döntésekben saját adataink szerint. Ezek közül az énhatékonyság összefügg a jobb anyagi körülményekkel és az anya magasabb iskolai végzettségével, valamint az egyszülős családok gyermekei is nagyobb énhatékonyságról számoltak be. Ez az eredmény a várttal ellentétes lehet, azonban korábbi kutatások is beszámoltak hasonlóról, aminek magyarázata az ilyen helyzetben lévő gyermekek nagyobb alkalmazkodóképességében rejlik $[5,31]$.
A táplálkozással és étrendválasztással kapcsolatos döntésekben fontos szerepet játszik az információforrás eredete $[12,14,15]$. Faktoranalízissel három faktor különült el vizsgálatunkban. A szakértői források az iskolában tanultak mellett az orvosi és egyéb szakértői ismeretekre és tanácsokra épülnek, szemben a laikus forrásokkal, amelyek televízióműsorokból, magazinokból és informális forrásokból állnak össze. A szakértői információt elsősorban a lányok, a gimnazisták és a jó tanulók választják, szemben a laikus forrásokkal, amelyeket a fiatalabbak, a falun élők, a szakiskolában tanulók és az iskolában roszszabbul teljesítők. A harmadik faktor speciális helyet foglal el: úgy tűnik, aki az internet világából tájékozódik, más forrásokra nem is igazán támaszkodik. Az internet mint egészségügyi információforrás egyre nagyobb teret kap $[14,15]$. Az adatokból kiderült, hogy az internethasználat mint a táplálkozással kapcsolatos információforrás összefügg az énhatékonysággal és az anya magasabb iskolai végzettségével, a magatartási és attitűdbeli faktorok közül pedig a tudatos nyersétel-alapú táplálkozással, jelezve a tudatos keresést és választást.

\section{Következtetések}

Megállapíthatjuk, hogy a serdülők részben egészségtudatos módon választják meg étkezési szokásaikat, részben azonban jelen van az egészséges táplálkozást nem preferáló vagy elutasító, illetve helyenként ambivalens hozzáállás is. Ennek oka lehet, hogy az egészséges táplálkozást illetően sokféle nézőpont van jelen az egyes diétatípusoktól (például nyersétel-alapú, vegetáriánus stb.) függően [24], amelyek megítélése is folyamatosan változik. Lehetnek külső akadályok is, mint az anyagiak vagy a szülők iskolázottsága, illetve az adekvát információforrások megtalálása.

Kutatásunk korlátaiként meg kell említeni, hogy bár igyekeztünk több szinten vizsgálni a fiatalok táplálkozását, bevonva a magatartás, az attitüd és az információ elemeit is, számos szempontot kihagytunk, és elsősorban az egészséges és kevésbé az egészségkockázatos ételekre koncentráltunk. Egyéb szempontok figyelembevétele, például a motivációk, az ételpreferencia vizsgálata szintén jövőbeli kutatások tárgyát képezheti. Annál is inkább, mert számos korreláció nagyságrendje viszonylag alacsony, így az egyéb tényezők felkutatása fontos lehet. Az önbeszámoláson alapuló módszer mellett az étkezési magatartás felméréséhez igen hasznos lehet az úgynevezett táplálkozási napló alkalmazása, ami növelheti az adatok validitását [29]. Az információforrásokkal kapcsolatban is óvatosnak kell lennünk, hiszen ezen a téren a kínálat túlméretezett, még a szakmainak tartott információk is gyorsan változnak, időnként ellentmondásosak, nem is beszélve az ellenőrizhetetlen reklámanyagokról.

Végül, mintánk nem reprezentálja a teljes hazai serdülőpopulációt, országos reprezentatív mintán végzett vizsgálat tenné csak lehetővé az eredmények általánosítását. 
Adataink arra hívják fel a figyelmet, hogy a serdülők táplálkozási szokásainak megismerése rendkívül fontos, nemcsak a magatartás, hanem az attitűd és az információ szintjén is. Ez az életszakasz e szempontból igen kritikus, hiszen a gyermekkori táplálkozási szocializáció az egyre inkább autonómmá váló döntésekkel jelentősen módosulhat (sajnos, mint a kutatások igazolják, nem kedvező irányba, például gyorsételek, energiaitalok stb.) $[7,10,11]$. A prevenciós programok a leggyakrabban a szerfogyasztási formákra fókuszálnak, pedig az egészségtudatos táplálkozás kialakítása szintén fontos prioritást kell, hogy képezzen.

Anyagi támogatás: A közlemény megírása, illetve a kapcsolódó kutatómunka anyagi támogatásban nem részesült.

Szerzői munkamegosztás: Sz. K.: A mérőeszköz elkészítése, adatfelvétel, -rögzítés és -elemzés, a közlemény megírása. P. B.: A mérőeszköz elkészítése, adatelemzés, a közlemény megírása. A cikk végleges változatát mindkét szerző elolvasta és jóváhagyta.

Érdekeltségek: A szerzőknek nincsenek érdekeltségeik.

\section{Irodalom}

[1] McGinnis JM, Williams-Russo P, Knickman JR. The case for more active policy attention to health promotion. Health Aff (Millwood). 2002; 21: 78-93.

[2] Verhagen H, van Loveren H. Status of nutrition and health claims in Europe by mid 2015. Trends Food Sci Technol. 2016; 56: $39-45$.

[3] Erdei G, Kovács VA, Bakacs M, et al. Hungarian Diet and Nutritional Status Survey 2014. I. Nutritional status of the Hungarian adult population. [Országos Táplálkozás és Tápláltsági Állapot Vizsgálat 2014. I. A magyar felnőtt lakosság tápláltsági állapota.] Orv Hetil. 2017; 158: 533-540. [Hungarian]

[4] Freedman DS, Khan LK, Serdula MK, et al. The relation of childhood BMI to adult adiposity: the Bogalusa Heart Study. Pediatrics 2005; 115: 22-27.

[5] Fülöp N, Szakály Z. Nutrition habits of young people, healthattitude - secondary market research. [Fiatalok táplálkozási szokásai, egészségmagatartása - szekunder kutatás.] Élelm Táplálk Mark. 2008; 5: 81-86. [Hungarian]

[6] Corkins MR, Daniels SR, de Ferranti SD, et al. Nutrition in children and adolescents. Med Clin North Am. 2016; 100: 1217 1235.

[7] Pikó B, Keresztes N. Nutritional control among high school students: social influences of eating behavior and characteristics of their gender differences. [Táplálkozáskontroll középiskolások körében: Az étkezési magatartás társas összefüggéseinek nemek szerinti jellegzetességei.] Mentálhig Pszichoszom. 2008; 9: 149164. [Hungarian]

[8] Németh Á, Költő A. (eds.) Health and health behaviour in school-aged children. A WHO collaborative cross-national study - National Report 2014. [Egészség és egészségmagatartás iskoláskorban. $\mathrm{Az}$ iskoláskorú gyermekek egészségmagatartása elnevezésú, az Egészségügyi Világszervezettel együttmúködésben megvalósuló nemzetközi kutatás 2014. évi felméréséről készült nemzeti jelentés.] Nemzeti Egészségfejlesztési Intézet, Buda- pest, 2014. http://mek.oszk.hu/16100/16119/16119.pdf [accessed: May 5, 2017]. [Hungarian]

[9] Kuźbicka K, Rachoń D. Bad eating habits as the main cause of obesity among children. Pediatr Endocrinol Diabetes Metab. 2013; 19: 106-110.

[10] Moreira NF, da Veiga GV, Santaliestra-Pasías AM, et al. Clustering of multiple energy balance related behaviors is associated with body fat composition indicators in adolescents: results from the HELENA and ELANA studies. Appetite 2018; 120: 505513.

[11] Szabó K, Pikó B. The correlation of eating behavior with food preference motivation and personality related factors among adolescents. [Az étkezési magatartás összefüggése az ételválasztási motivációkkal és egyes személyiségbeli jellemzókkel középiskolások körében.] Egészségfejlesztés 2017; 58: 5-16. [Hungarian]

[12] McKinley MC, Lowis C, Robson PJ. It's good to talk: Children's views on food and nutrition. Eur J Clin Nutr. 2005; 59: 542551.

[13] Lally P, Bartle N, Wardle J. Social norms and diet in adolescents. Appetite 2011; 57: 623-627.

[14] Kiss VÁ, Szakály Z. The health consciousness of youngsters regarding their nutrition habits. In: Bíró-Szigeti Sz, Petruska I, Szalkai Zs, et al. (eds.) Marketing on network and beyond. [A fiatalok egészségtudatossága a táplálkozási szokásaikat illetően. In: Bíró-Szigeti Sz, Petruska I, Szalkai Zs, et al. (szerk.) Marketing hálózaton innen és túl.] Az Egyesület a Marketing Oktatásért és Kutatásért XXI. országos konferenciájának tanulmánykötete. Budapesti Műszaki és Gazdaságtudományi Egyetem, Budapest, 2015; pp. 145-154. [Hungarian]

[15] Ghaddar SF, Valerio MA, Garcia CM, et al. Adolescent health literacy: The importance of credible sources for online health information. J Sch Health 2012; 82: 28-36.

[16] Cusatis CD, Shannon BM. Influences on adolescent eating behavior. J Adolesc Health 1996; 18: 27-34.

[17] Renner B, Schwarzer R. The motivation to eat a healthy diet: how intenders and nonintenders differ in terms of risk perception, outcome expectancies, self-efficacy, and nutrition behavior. Polish Psychol Bull. 2005; 36: S7-S15.

[18] Burg J, Lechner L, de Vries H. Psychosocial determinants of fruit and vegetable consumption. Appetite 1995; 25: 285-296.

[19] Kelloniemi H, Ek E, Laitinen J. Optimism, dietary habits, body mass index and smoking among young Finnish adults. Appetite 2005; 45: 169-176.

[20] Serlachius A, Pulkki-Råback L, Juonala M, et al. Does high optimism protect against the inter-generational transmission of high BMI? The Cardiovascular Risk in Young Finns Study. J Psychosom Res. 2017; 100: 61-64.

[21] Renner B, Schwarzer R. Social-cognitive factors in health behavior change. In: Suls J, Wallston KA. (eds.) Social psychological foundations of health and illness. Blackwell Publishing, Malden, MA, 2003; pp. 169-196.

[22] Adriaanse MA, Kroese FM, Gillebaart M, et al. Effortless inhibition: habit mediates the relation between self-control and unhealthy snack consumption. Front Psychol. 2014; 5: 444.

[23] de Ridder DT, Lensvelt-Mulders G, Finkenauer C, et al. Taking stock of self-control: a meta-analysis of how trait self-control relates to a wide range of behaviors. Pers Soc Psychol Rev. 2012; 16: 76-99.

[24] Szúcs V, Szabó E, Bánáti D. Exploration of healthy nutrition attitudes using a questionnaire survey. [Az egészséges táplálkozással kapcsolatos attitűdök feltárása kérdőíves megkérdezés alapján.] Orv Hetil. 2015; 156: 636-643. [Hungarian]

[25] Kopp MS, Schwarzer R, Jerusalem M. Hungarian questionnaire in psychometric scales for cross-cultural self-efficacy research. Zentrale Universitäts Druckerei der FU Berlin, 1993.

[26] Scheier MF, Carver CS. Optimism, coping, and health: Assessment and implications of generalized outcome expectancies. Health Psychol. 1985; 4: 219-247. 
[27] Bérdi M, Köteles F. The measurement of optimism: the psychometric properties of the Hungarian version of the revised Life Orientation Test (LOT-R). [Az optimizmus mérése: Az életszemlélet teszt átdolgozott változatának (LOT-R) pszichometriai jellemzői hazai mintán.] Magy Pszichol Szle. 2010; 65: 273-294. [Hungarian]

[28] Tangney JP, Baumeister RF, Boone AL. High self-control predicts good adjustment, less pathology, better grades, and interpersonal success. J Pers. 2004; 72: 271-324.

[29] Bíró L, Arató Gy, Antal E, et al. National representative study of nutrition among 11-18-year-olds. [11-18 évesek országos reprezentatív táplálkozási felmérése.] A Magyar Táplálkozástudományi Társaság XLII. Vándorgyúlésén elhangzott előadás, Siófok, 2017. október 12-14. p. 21. https://www.doki.net/ tarsasag/taplalkozas/upload/taplalkozas/document/xlii_vandorgyules_programja_20171030.pdf?web_id [accessed: June 6, 2018]. [Hungarian]

[30] Bere E, van Lenthe F, Klepp KI, et al. Why do parents' education level and income affect the amount of fruits and vegetables adolescents eat? Eur J Publ Health 2008; 18: 611-615.

[31] Kurtz L, Derevensky JL. The effects of divorce on perceived selfefficacy and behavioral control in elementary school children. J Div Remarriage 1993; 20: 75-94.

(Dr. Fűzné Dr. Pikó Bettina, Szeged, Szentháromság u. 5., 6722 e-mail: fuzne.piko.bettina@med.u-szeged.hu)

\section{PÁLYÁZAT}

A Prof. Dr. Romics László Akadémikus Emlékére Alapítvány pályázatot hirdet Magyarországon dolgozó, magyar állampolgárságú, 40 éven aluli orvosok és orvosbiológiai kutatással foglalkozó személyek számára. A nyertes pályázó(k) között $500000 \mathrm{Ft}$ alapítványi adomány kerül kiosztásra.

A pályázat célja: a klinikai gyógyítás vagy orvosi tudományos kutatás területén dolgozók kiemelkedő tudományos tevékenységének elismerése.

Elönyt élveznek azok a pályázók, akik az alapítvány névadójának munkásságát folytatva cardiovascularis és anyagcsere-betegségek területéről nyújtanak be pályázatot.

A pályázat benyújtásának határideje: 2019. január 31. (elbírálásának határideje: 2019. április 30.)

A pályázatot a palyazat@romicsalapitvany.hu e-mail címre pdf formátumban kell benyújtani.

A pályázatot természetes személy, saját nevében, magyar nyelven nyújthatja be, a pályázati anyag ábrák nélkül maximum 15000 leütés (karakter) terjedelmű lehet. A pályázathoz mellékelni kell egy rövid szakmai életrajzot a születési év megjelölésével.

A pályázat benyújtását saját kézzel aláírt és dátummal ellátott levélben kell bejelenteni az alapítvány titkárának címezve (a borítékra írandó cím: dr. Dudás Márta, 1461 Budapest, Pf 62.) könyvelt (ajánlott) küldeményben, mert ezen bejelentés alapján válik hitelessé a pályázat. A pályázatot nyomtatott formában nem kell mellékelni.

Az alapítvány adatairól, müködéséről a www.romicsalapitvany.hu honlapon található információ. 